University for Business and Technology in Kosovo

UBT Knowledge Center

UBT International Conference

2013 UBT International Conference

Nov 1st, 3:45 PM - 4:00 PM

\title{
The Impact of Socialist Realism Ideology in the Albanian Architecture from 1945-1990
}

Olisa Ndreçka

Polytechnic University of Tirana, o.ndrecka@gmail.com

Florian Nepravishta

Polytechnic University of Tirana, f_nepravishta@yahoo.com

Follow this and additional works at: https://knowledgecenter.ubt-uni.net/conference

Part of the Architecture Commons

\section{Recommended Citation}

Ndreçka, Olisa and Nepravishta, Florian, "The Impact of Socialist Realism Ideology in the Albanian Architecture from 1945-1990" (2013). UBT International Conference. 7.

https://knowledgecenter.ubt-uni.net/conference/2013/all-events/7

This Event is brought to you for free and open access by the Publication and Journals at UBT Knowledge Center. It has been accepted for inclusion in UBT International Conference by an authorized administrator of UBT Knowledge Center. For more information, please contact knowledge.center@ubt-uni.net. 


\title{
The Impact of Socialist Realism Ideology in the Albanian Architecture from 1945-1990
}

\author{
Olisa Ndreçka ${ }^{1}$, Florian Nepravishta ${ }^{2}$ \\ 12 Polytechnic University of TiranaFaculty of Architecture and Urbanism \\ Tirana, Albania \\ o.ndrecka@gmail.com ${ }^{1}$, f_nepravishta@yahoo.com ${ }^{2}$
}

\begin{abstract}
The socialist Style in the Eastern European countries was considered a great style. It was called the "proletariat style" that combined the communist ideology with the artistic image, a style that was socialist in content and national in form. Construction and Architecture in Albania after the Second World War until 1990, exactly for 45 years, were guided by certain principles, as aesthetic design concepts, as well as the norms and rules that were binding and strong for architects. "Canons" funnel architects relations with the government and the Party. The paper treats: historical description of socialist realism, the initial development of the architecture of the socialist realism in Albania, the influence of the decisions of the Labor Party of Albania (PPSH), how the Albanian architecture and the development conditions of the constructions were radically changed by the ideas of the socialist realism, how this style was strongly supported by the post-war architects, graduated in East and by the Soviet architects.
\end{abstract}

Keywords: socialist realism, architecture, ideology, dictatorship

\section{Introduction}

Totalitarian regimes are characterized by attempts to control everyone and everything at any cost; by force and propaganda, they impose a single truth about the world and people. Lenin's Bolshevik revolution in 1917 is conducted in the name of socialism and proletarian state power passes under the control of the party. After the Second World War the Soviet Union carried out a powerful invasion in many countries of Eastern Europe. Albania entered into the fold of Soviet Union, "impatient" to pay tribute to Stalin. New elements of the Stalinist economic system, urban planning and design were imposed. The relationship between architecture and politics is one of the dominant themes devoted to Albanian architecture from 1945-1990. Although the beginning of '90s was the end of the Socialist realism period in Albania still today, there is a "strange "approach to the heritage of that period. In fact, this is one of the main problems. First, it is not considered as a contribution in the Albanian history of architecture; on the contrary, there is a continued demand to destroy any trace or proof of the socialist realism period. Secondly, there are damages, destruction and loss of identity for the buildings that date back to that period. Thirdly, there is Lack of Maintenance and total abandonment phenomenon that make this heritage almost unrecoverable.

\section{Historical Description of Socialist Realis m in Architecture}

Socialist realism is a style of realistic art, which was developed in the Soviet Union and became a dominant style in other socialist countries. Socialist realism is a teleologically-oriented style having as its purpose the furtherance of the goals of socialism and communism.

During the October Revolution of 1917, the Bolsheviks established an institution called Proletkult (the Proletarian Cultural and Enlightenment Organizations) which sought to put all arts into the service of the dictatorship. Socialist realism became state policy in 1932 when Soviet leader Joseph Stalin promulgated the decree "On the Reconstruction of Literary and Art Organizations". Accordingly, the 
Moscow and Leningrad Union of Artists was established in 1932, which ended the history of postrevolutionary art. The epoch of Soviet art began..The style of socialist realism, according to Anders Aman, appeared for the first time in 1933 in the Soviet Union on the occasions of the national competition for the Palace of the Soviets in Moscow [1]. In fact, in February 1931, soviet architects received invitations to bid for the Palace of Soviets design. Until February 1933, several contests were held and many architects participated, but there was not any winner.

To indoctrinate the masses, the socialist realism ideology was also forced in the arts and sciences, culture, and architecture. This ideology became popular not only in the Soviet Union, but also among other eastern European countries, such as Romania, Bulgaria, Hungary, Czechoslovakia, Yugoslavia and so forth.

The congress of Architects in 1937 (Union Congress of All Soviet Architects, in June 19), was a very important event for Soviet architecture. In this congress was drafted the code of Socialist Realism architecture, which states: "The proletariat must create a style in Architecture"[11]. The Soviet architecture, borrows the form from the past, essentially by ancient Greek architecture that should incorporate new content with the old form. The only valid architecture by the Congress, is the classic architectural style, as literature requires a red Tolstoy, also architecture should have a red Palladio. In conjunction with the Socialist Classical style of architecture, Socialist realism was the officially approved type of art in the Soviet Union and in the Eastern European countries. All material goods and means of production belonged to the community as a whole; this included means of producing art, which were also seen as powerful propaganda tools. Architecture in the former Soviet Union during the Socialist realism period was called also Stalinist architecture, considering that the Soviet Union was under the leadership of Joseph Stalin Stalinist architecture is associated with the socialist realismschool of art and architecture.

\section{The Initial Development of the Architecture of the Socialist Realis m in Albania}

The Albanian Communist Party and his leader Enver Hoxha gained power in Albania in 1944. During the following years, the Soviet economic, political and ideological model was introduced in Albania, which became one of the strongest communist states, totally isolated from the rest of the world after 1978 when all connections to other countries had been broken. Hoxha ruled Albania as a dictator until his death in 1985. Albania was then the poorest country in Europe.

The communist ideology was reflected in the physical environment, which was changed in a harsh way during this period. New towns were built as well as many huge industries, city centers of existing cities were re-constructed, statues and monuments were raised and street names were changed. Historical buildings that did not suit the dictatorship were torn down. Religious buildings were demolished or turned into profane buildings since Albania in theory was an atheistic state. Construction and Architecture in Albania after the Second Word Ware until 1990, exactly for 45 years, were guided by certain principles of socialist realism, as aesthetic design concepts, as well as the norms and rules that were binding and strong for architects.

There were radical changes in social and economic structure, because of the ideas of socialist realism. In terms of architecture, after the war, the style, the "direction" or "language" of the Albanian architecture and urban planning was expected to be chosen. Almost all the options, where to choose the "direction" and the style from the examples of countries of Central and Eastern Europe, although in many Albanian cities were laid solid foundations of the Italian rationalist architecture, MIAR (Movimento Italiano di Architettura Razionale).

Albanian architecture "decided" and underwent the method of socialist realism. The Genesis of the Albanian architecture, in the communist period is found in Social realism theory and practice of the Soviet Union, namely the Congress of Architects in 1937. 


\section{The Soviet Influence}

The Soviet influence was absolute, but from the years 1947-48 Albania was also under the influence of Yugoslavia, that had built up under the influence of western country's architecture, at least, Yugoslavia did not blindly follow the canons of socialist realism of the Soviet Union. From $1951-52$ the first Albanian architects of the post-war who had studied in the Soviet Union, after completing the studies began working at home, and later supported by many others who came from the popular democracies of Eastern Europe, Soviet satellites, as our country was. The latter ones were closer to the idea of contemporary architecture, thanks to a tradition rooted in these countries before the war. Education in the prevailing spirit of the time, consequently brought projects that strictly followed the Soviet example. Any deviation was called "antisovjetizem" and was punished. Punitive measures were conditioned by the status or class of the society of the individual and also their political credibility. Among the first buildings built in Albania that reflected the socialist style were; Industrial buildings such as "Stalin Textiles Factory", designed by the Soviet and built in the early 50'in the suburbs of Tirana, and Faculty of History and Philology. Kino studio "New Albania" was designed again by the Soviet and built in 1951-1952 in Tirana. The Soviet project was correctly implemented. In the main boulevard of Tirana, the Central committee of Labor Party of Albania is another example of the Soviet influence in the Albanian architecture in that period. (Figure 1,2,3)

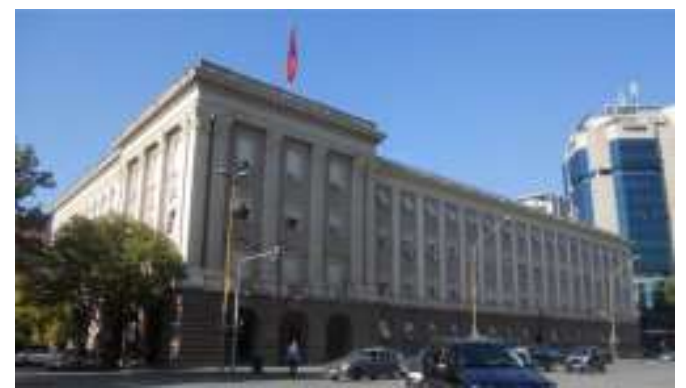

Fig. 1. Former Central Committee of Labor Party of Albania.

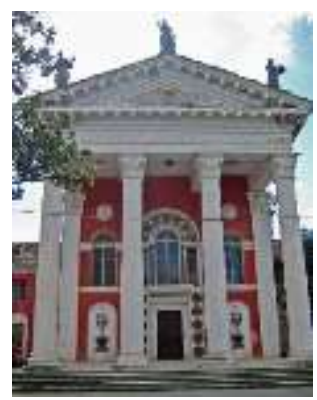

Fig. 2. Kino studio "New Albania".

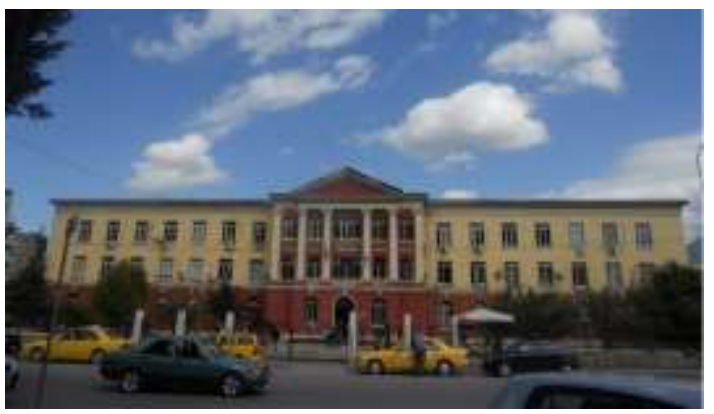

Fig. 3. Faculty of History and Philology. 
This situation continued until 1955-56. At that time, there was a turn in the XIX Congress of the Communist Party, in the Soviet Union, that revised the official history. Therefore, the rehabilitation of the contemporary architecture was made, and the current stream known at that time as regressive and archaic was criticized because it was obligatory in the 1930s. Before these years, the architecture was better compared to the world architecture. Even in our country, the ten years - experience was criticized due to the phenomenon that happened in the Soviet Union, because we quickly got used to their policy. The criticism focused on the excessive and the pointlessness decoration of the facades, while the core remained intact, planning through the urban policies, an industrial-agrarian development of the country where $70 \%$ of the population was situated in the villages. The unneces sary ornamentation was removed. Furthermore, the facilities built with low quality available materials, and without exterior plastering seemed poor. The architects had design requirements or prescribed conditions. For this reason the opportunities for something new, were restricted for usual facilities. Obviously, there were requests from the government for buildings of special importance. In such cases, the architecture had to make use of new ways of conception, and also construction with new good quality materials. This was a model also in Albania. Lack of decorations and many other elements that characterize the style of architecture up to that period for Albania, was considered as construction cost reduction, and loyalty to the Soviet Union decisions.

For several years, the Stalinist architecture was a model. The break of the relations with the former Soviet Union marks a relatively difficult period in the Albanian architecture in the early '60s. After the break of the relations, the friendly warm period in which the maximum was obtained from architectural projects and professionals from the former Soviet Union, ended. Many buildings (even some very important) were "abandoned", and Albanian Engineers and architects were forced to continue the construction of these major works by making changes, without excluding Stalinist ideology, but bringing it in the best rational form. The Palace of Culture was one of these buildings. It was built on the former Tirana's Old Bazaar. The first stone was symbolically put by the former First Secretary of the Communist Nikita Khrushchev in 1959. The building was a gift for Albanians from the Russian government. The Russian design group presented three versions of the project. The Politburo selected the winning version. In this version, changes should be made, so a part of Soviet designers stayed in Albania to correct the project- idea, also Albanian architects and engineers group took part to help in the matter.(Figure 8,9)

After finishing the project, the Russian staff left, keeping in touch with the group of designers, sending the project partially. The Albanian group of designers never had the full project design, so the break of the relations, caused a very big "cramp" for the work progress. The Work began followed by the drawings and supplements to the existing drawings, so that the project could be as close as possible to the soviet one. Meanwhile, the Party and the government wanted the Palace of Culture to become larger. As a result, the program was extended and the number of floors was increased, a library space was added even though it was not part of the project designed by the Soviets.(Figure $4,5,6,7$ )

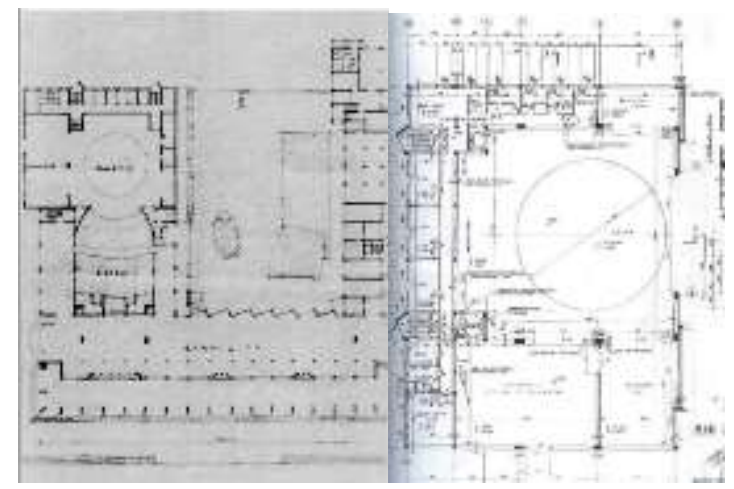

Fig. 4. The palace of Culture, the ground floor plan. plan.

Fig. 5. The palace of Culture, the second floor 


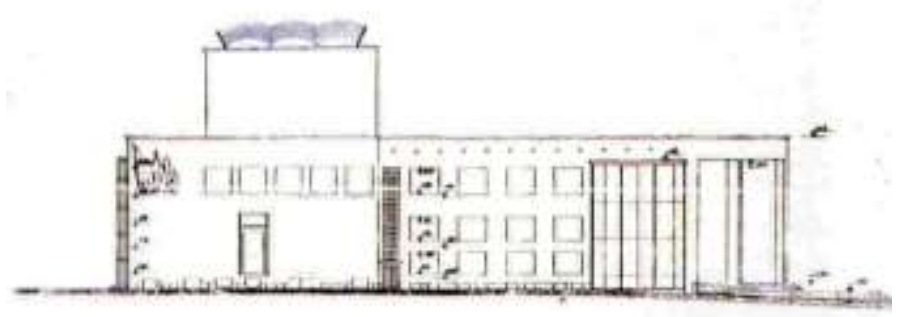

Fig. 6. The palace of Culture, section.

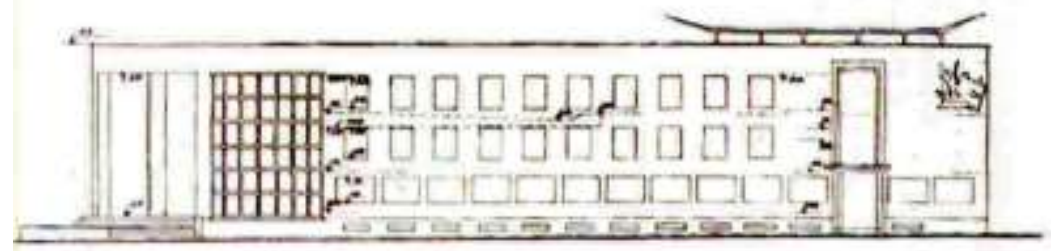

Fig. 7. The palace of Culture, section.

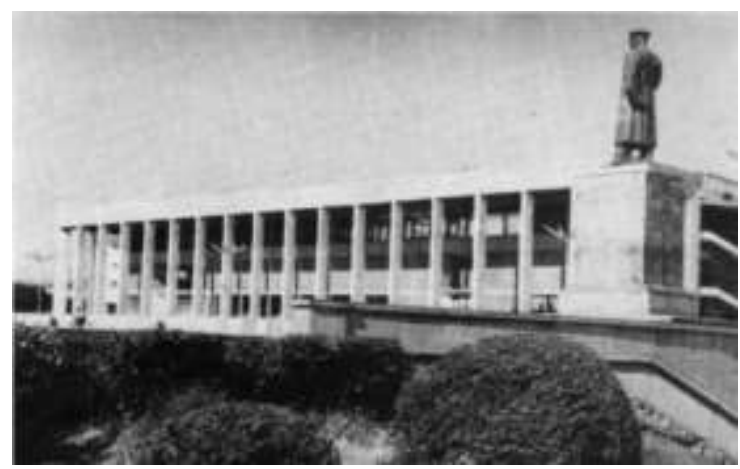

Fig. 8. The palace of Culture in the ' 60 .

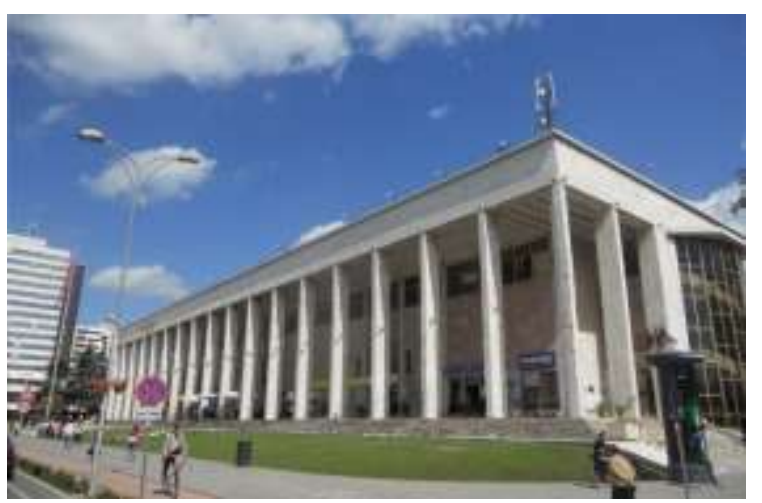

Fig. 9. The palace of Culture. 


\section{The Influence of the Labor Party of Albania}

The Genesis of socialist realism architecture in Albanian can be found in the decisions of the Labor Party of Albania and the totalitarian government. In the Politburo meetings that used to be called "Plenum", were processed and approved guidelines, thes is, principles, and codes. This style, in Albania was strongly supported by the group of the post-war architects, graduated in the universities of architecture in the former Soviet Union, and in other countries of the former communist camp, and it was also supported by the creativity of Soviet architects who were invited to design very important buildings in Albania.

The Party and the government led the policy of the construction and architecture in Albania, observing the Ministry ofConstruction as the principal institution in charge for designs, urban studies, engineering and architectural buildings. First buildings of the socialist realism in Albania are those with social, administrative and cultural character. The socialist realism style in the Albanian architecture was treated as a political and ideological approach, and was always mentioned by political propaganda, that this style is strong and conceived in such way to fight against the foreign architectural models of the capitalist countries. After the 1960, Albania, as a poor country met the demands, for a rational, simple and functional architecture based on the modern technology of that time, and the industrialization of construction. The method of socialist realism style was always a political dogma, because it had no executive value, It did not help as a design instrument. The socialist Content and the national forms remain only slogans.

"Let's build quickly good, and cheap." This slogan should have been followed, and under this motto were built most of the buildings in Albania.

In many cas es, the architect's initiatives and attempt to "dare" "in functional and constructive solutions, or in the design of facades, were immediately rejected, claiming that these solutions would be costly. Architect of the time stated that: there was the ministry team of control that in separate social circles was called the "saving team that although the design of the facilities had a low budget, again there attempts to reduce the cost. For this reason, we can say that many of the buildings constructed in communist Albania could have been better. The influence of the party was present in the life of everyone because, under the socialist systemthere was a rigid rule that all specialists, as Party cadres, were under the management of a department (dikaster), in order to exercise centralized control. Whenever the architects wanted to have new bonds, the main instances were not satisfied. The project process was closed; it had to do with the constructing matter, not accepting its artistic attributes, since the construction itself was included in economical plans.

According to Hoxha "anything that will be built, will serve the masses, because they will live in these built cities, will walk in their streets and will enjoy the sunlight that will penetrate everywhere"[4].

The most important part of architecture, the artistic side, was left aside, neglected but was considered only on special occasions. Only the government, the Party, chose the facilities where the ornaments could be used. The key element in the construction matter was the functional solution. Every extra request was regarded as excessive and finally was not accepted. Following this method, the progress was very difficult. The technical councils were the only place where the discussions were held. It was up to the department functionary to make decisions on the matter. There were numerous cases when the Communist Party, present more than ever, was "revolted "against the professional's attempts to design and project facilities in a modern style, the so-called revisionist (or words ending in -ism) used at that time. The system had a policy; building low cost living facilities, and building the administrative state facilities with relatively high budget (considering the poverty in Albania. The initiatives and attempts of the architects, not to follow the rules, as mentioned above, were eliminated immediately, but there were courageous architects whose designs and works were attacked and punished from the system because of economical, ideological and political reasons.

An example of this is Maks Velo's residential building named as "Dice residential building". The building attracted the attention of the people, and certainly, was considered a trend towards cubism, not only by those who in a hidden way, shared the same opinion, but also by the ones who were insistent and mean and attacked the work together with its architect. The centrally located building would be a continuous provocation for the designing and projecting way of the time. The building itself would be a target of charges, especially after the architect was sentenced in prison. The building sometimes was called modernist, cubist and the government were in favor of its demolition.(Figure 10,11) 


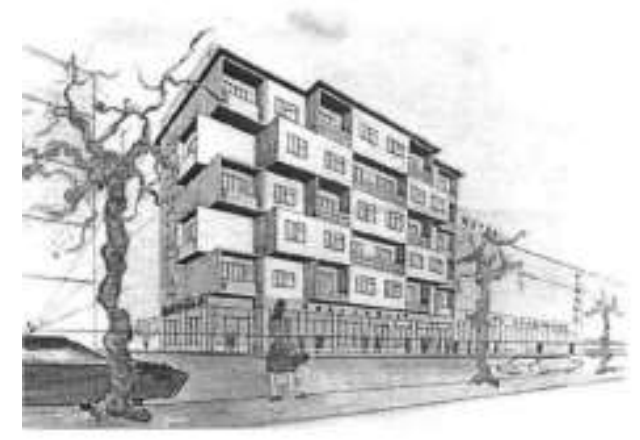

Fig. 10. Perspective Drawing of the Residential Building.

In an article in "Drita" newspaper was written; The cost of an apartment was doubled, in the residential building next to the store department (called Mapo). There was a drawback in designing the apartment, there was living and service unjustified space, of different sizes and shapes. Because of the "free architecture" the façade, not only has not functional balconies, but the foreign impact also affected the function and the facade of the building. The impact was immense in the economic aspect, because the budget used in this building, would be enough for building twice the number of the apartments. The contradict comes from the foreign impact and trend. The saving regime is strengthened by the beauty and simplicity, which is in harmony with the national style, contradicting the redundancy, the luxury and the overuse of expensive materials.

Despite the written and spoken comments, the project of this building normally was introduced in the technical counsel as well as another special commission of the Ministry of Construction that purposely checked this building. As mentioned above, for the buildings that were considered important for the government, there was a considerable budget and for their design, the most successful architect was called. The National Historical Museum was one of the buildings, and the government had great requirements and expectations of its construction. The impact of the party, stronger than ever decided and assigned how it should be designed and built. "The museumstands as a monument which the party raised in the glorious and heroic history of our country in centuries "was said in one of the newspapers of that time.

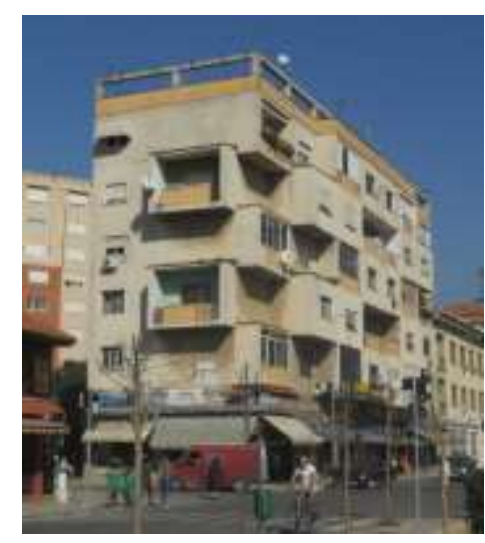

Fig. 11. Photo of the Residential Building.

The National Historical Museumwas inaugurated on 28 October in 1981, and is one the biggest museum institution in Albania. Located in the western side of the square of "Skanderbeg", the museum is one of the most important architectural works, playing an important role in the urban formation of the center of Tirana.(Figure 12)

In the first ages of the project, frequent meetings with the government were inevitable, because their thoughts and suggests, served as a solid foundation for the development of the project. In Enver Hoxha's works, there are certain remarks regarding the construction of the National Historical Mus eum in terms 
of, its volume and the impact of the ideology used for the design of the bu ilding. He was dis satisfied for the lack of the political, ideological, cultural and military concepts in the content of the museum, and he urged to reveal (from this building) the Marxism-Leninism point of view.

The dictator himself did not hesitate to give his opinion on the architectural concept, forcing the professionals not to have extravagant ideas about graceful and gigantic buildings. On the contrary, they had to give the museum national and traditional features. There were more and more orientations and suggestions, and there were comparisons and parallelism such as "the belt of ammo", as an identifying element or symbol of the national war of liberation, leaded by the communist party. Such interventions were at some extending harsh, when intervening in the creative process and the work of the architect[4].

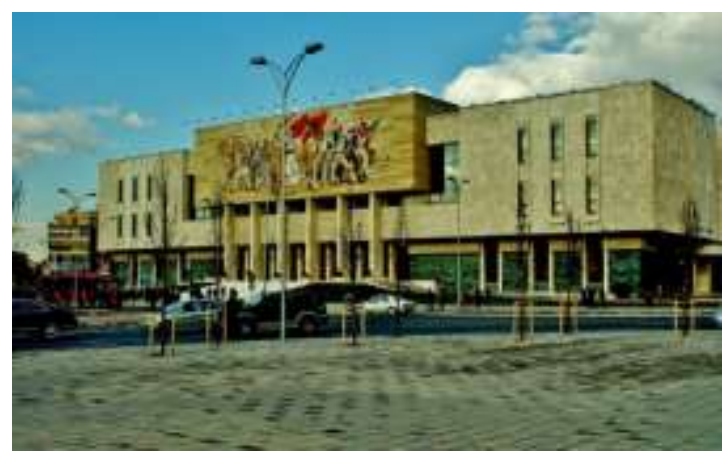

Fig. 12. Photos of the National Historical Museum.

\section{Discussion and Conclusions}

For several years, the Socialist realism style was a model for the Albanian architecture and urban planning. After the break of the relations with the former Soviet Union, the ideology led the policy the construction and architecture by the directives of the Communist party. The ideology led the policy of the construction and architecture in Albania during 1945-90 and this heritage needs to be preserved for next generations. The socialist realism ideology affected not only a few culture, media and publicpolitical buildings, but also social, educational and service buildings. The common point of view among the people is to totally forget, destroy any memories facts and buildings of that period, maybe these happens because the communist period is still recent and many Albanians directly or indirectly suffered during this period, but on the other hand, there are several buildings considered as communist heritage that carry culturalvalues and represent an important period in the Albanian architecture. The communist heritage should be recognized from the younger and future generations, and the best way is to give a possibility to better understand the past of their society as well as the present and themselves. There are several facilities/ buildings that are regarded as important examples of architecture and ideology, and they represent aesthetics and functionality features. The socialist realism ideology affected the landscape and cityscape in almost every aspect of architecture and urban planning. The most imp ortant thing to do with the built heritage from this period is; to not divide buildings constructed in that period, from the history of Albanian architecture. Although this is considered hard to do in a culturallandscape produced and transformed by a dictatorship, because some of the buildings clearly belong to the system's ideology. Many other elements and shapes of this architecture are found again in later buildings that were constructed after the 1990's creating, so a stereotype of the architectural elements used mainly by the architects. The rest of the remaining heritage, part of the Albanian architecture in socialist realism, should neces sarily be preserved because; Despite the conditions of the political system, the attempts of a great number of architects, succeeded in projecting many buildings that even today have a special and noticeable importance. It is an asset of that period in the field of designing and constructing that reveals the mentality of that system. It reflects and transmits the concepts and ideological principles of the architecture of the time. Even though the economic capacity was unsatisfactory, the values of the tradition and heritage shown in the buildings could also be noticed in the field of design and construction. 


\section{References}

1. Åman, A. A.(1992), Architecture and Ideology in Eastern Europe during the Stalin Era : an aspect of Cold War history (Cambridge: MIT Press)

2. Bego, B. M. (2009). Skeda Arkitekture 1965- 2004 Ne kroniken e nje jete te dallgezuar, Monografi: Ceshtja e strehimit ne periudhen e socializmit real.Shtypi:Gent Grafik.

3. Caushi, C. T. (1975)Estetika ne edukimin komunist. Shtypshkronja"8 Nëntori"

4. Hoxha, H. E. (1977) - Vëllimi 62 Korrik 1977-Nëntor 1977

5. Pirgu, P. I.(2011) Semih Pashallari Arkitekti i heshtur.Shtepia botuese ILAR

6. Velo, V. M.(1998) Paralel me arkitekturën.Shtepia botuese ILAR

7. Ivanov, I. V.S. (2007)Unknown Socialist Realism.The Leningrad School

8. Instituti i Historisë. (1983)Historia e Shqipërisë, Vëllimi i katërt (1944-1975),

9. Drita newspaper, march $5^{\text {th }} 1972$

10. Dmitry Khmelnitsky. Stalin the Architect(2007)

11. http://gazeta55.al/index.php?artikulli=17188

12. http://en.wikipedia.org/wiki/Socialist realis m

13. http://www.marxists.org/history/ussr/events/revolution/index.htm

14. http://history1900s .about.com/od/Russian-Revolution/a/Russian-Revolution.htm 